\title{
An Innovative Battery Protection Device Design That Eliminates Permanent Sulphation for Lead Acid Batteries
}

\author{
Detin VARAN ${ }^{1}$, (D) Ayetullah AKAR ${ }^{2}$ \\ ${ }^{1}$ Corresponding Author; Sakarya Uygulamalı Bilimler Üniversitesi, Elektrik-Elektronik Mühendisliği Bölümü; \\ mvaran@subu.edu.tr; https://orcid.org/0000-0001-6099-6768; +902646160317 \\ ${ }^{2}$ Sakarya Uygulamalı Bilimler Üniversitesi, Lisansüstü Eğitim Enstitüsü, Mekatronik Mühendisliği Bölümü; \\ y165045001@subu.edu.tr; https://orcid.org/0000-0003-4062-1429
}

Received 22 October 2019; Revised 13 December 2019 Accepted 28 December 2019; Published online 31 December 2019

\begin{abstract}
The most important criterion that determines the working quality of the batteries is the stability of the voltage level between the poles and the main reason for this stability is the sülfat sulphation ol phenomenon that occurs in battery electrolysis. Sulfatization may cause battery-critical failures such as short circuit between the plates in the battery and will result in the battery being replaced in less time than service time. In this study, a battery protection device is designed which can provide electrochemical reaction control by stimulating the battery with signals that can be adjusted with amplitude and frequency from the battery poles in order to reduce the sulfation problem of the batteries by performing electrochemical reaction control while waiting and waiting for the battery or to prevent the formation of permanent sulphation in lead acid batteries.
\end{abstract}

Keywords: lead acid batteries, sulfation, electrochemical reaction control, battery protection device design

\section{Kurşun Asit Aküler İçin Kalıcı Sülfatlaşmayı Ortadan Kaldıran Yenilikçi Bir Akü Koruma Cihazı Tasarımı}

Öz

Akülerde çalışma kalitesini belirleyen en temel ölçüt kutuplar arasındaki gerilim seviyesinin kararlılığı olup bu kararlılığı bozan temel sebep akü elektrolizinde meydana gelen "sülfatlaşma" olayıdır. Sülfatlaşma aküde plakalar arasında kısa devre oluşumu gibi akü açısından kritik arızalara sebebiyet verebilecek ve akünün servis süresinden daha kısa sürede değiştirilmesi ile sonuçlanacaktır. Bu çalışmada akülerde sülfatlaşma probleminin akü vazife görürken ve beklerken elektrokimyasal tepkime kontrolü yapılarak azaltılması veya kurşun asit akülerde kalıcı sülfatlaşmanın oluşumunun engellenmesi maksadıyla akü kutuplarından genliği ve frekansı ayarlanabilen sinyaller ile akünün uyarılarak elektrokimyasal tepkime kontrolü sağlayabilen bir akü koruma cihazı tasarımı yapılmıştır.

Anahtar Kelimeler: kurşun asit aküler, sülfatlaşma, elektrokimyasal tepkime kontrolü, akü koruma cihazı tasarımı

\section{Giriş}

Hareketli ve sabit güç ihtiyaçlarını karşılamada kullanılan aküler, yüksek güç seviyeleri için daha çok kurşun-asit ve nikel-kadmiyum çözeltilerinden sulu ve kuru tip olarak üretilmektedir. Günümüzde araç akülerinin \%95'i sulu tip akülerdir. Bu akülerin raf ömrü veya araca takılıp son müşteriye ulaştıktan sonra garanti süresi bitene kadar geçen sürecin yönetilmesi araç üreticileri için servis ve garanti süreçlerinde önemli bir role sahiptir. Garanti süreci sonrası için akülerin daha kısa hizmet ömrünün olması ulusal boyutta ekonomik ve çevresel zararlar vermektedir. Araçlarda kullanılan kurşun-asit bazlı akülerde elektrolit yoğunluğu akülerde şarj durumunun en temel göstergesidir. Yoğunluk, sülfatlaşma temelli çözelti içindeki asit miktarına bağlı olduğu gibi sıcaklıkla da değişmektedir. Bu durum akülerin çalışma ömrü üzerinde belirleyici bir role sahiptir. Aküde oluşan kurşun sülfat ince kristal yapıya sahiptir ve hali hazırda şarj akımı ile dönüşümü gerçekleşmektedir. Akü uzun süre şarj edilmediğinde oluşan bu ince kristal yapıdaki kurşun sülfat kalınlaşarak şarj akımı ile reaksiyona giremeyecek hale gelmektedir. Sülfatlaşma belirli bir sürede giderilemez ise aküde geri döndürülemeyecek ölçüde 
yıpranma ve arızalar görülmektedir. Tam deşarj durumuna karşılık gelen oda koşullarında 1,14 gr/cm3 - 11.5 V'dan küçük veya hücreler arası dengesi kaybolmuş olan akülerin, aracın şarj sistemi ile toparlanıp, dengelenmesi zordur. Bu durum sülfatlaşma önleyici mekanizmanın sürekli devrede kalmasını gerektirmektedir. Akü koruma cihazı ile akünün elektroliz reaksiyonlarının 1,28 gr/cm3 elektrolit yoğunluk değerini koruyacak şekilde kontrolünün sağlanması akünün çalışma sürekliliğini sağlamada önemlidir.

\section{Kurşun Asit Akülerde Elektrokimyasal Tepkimeler ve Sülfatlaşmanın Etkileri}

Hareketli ve sabit güç ihtiyaçlarını karşılamak üzere kullanılan aküler, günümüzde yüksek güç seviyeleri için daha çok kurşun-asit ve nikel-kadminyum çözeltilerinden sulu ve kuru tip olarak üretilmektedir. Kurşun-asit bazlı bir aküye ait elektrokimyasal tepkimeler anot ve katot için;

\section{Pozitif Plaka Elektrokimyasal Tepkimesi}

$$
\mathrm{PbO}_{2}+2 \mathrm{H}^{+}+\mathrm{H}_{2} \mathrm{SO}_{4}+2 e^{-} \stackrel{\text { Deşarj }}{\underset{\text { Sarj }}{\longrightarrow}} \mathrm{PbSO}_{4}+2 \mathrm{H}_{2} \mathrm{O}
$$

Negatif Plaka Elektrokimyasal Tepkimesi

$$
\mathrm{Pb}+\mathrm{H}_{2} \mathrm{SO}_{4} \stackrel{\text { Deşarj }}{\longleftarrow} \mathrm{PbSO}_{4}+2 \mathrm{H}^{+}+2 e^{-}
$$

Kurşun Asit Akü Genel Şarj-Deşarj Elektrokimyasal Tepkimesi

$$
\mathrm{PbO}_{2}+\mathrm{Pb}+2 \mathrm{H}_{2} \mathrm{SO}_{4} \underset{\text { Şarj }}{\stackrel{\text { Deşarj }}{\longrightarrow}} 2 \mathrm{PbSO}_{4}+2 \mathrm{H}_{2} \mathrm{O}
$$

şeklinde ifade edilir.

İdeal olarak sürekli tam şarjda olan ve oda koşulları ortamında tutulan bir akünün sülfatlaşma olayına maruz kalmayacağı kabul edilir. Bu şartların dışında meydana gelen sülfatlaşma olayında kurşun sülfat, ince kristal yapıya sahip olup ve hali hazırda şarj akımı ile reaksiyonu yani dönüşümü gerçekleşmektedir. (1), (2) ve (3) numaralı kurşun-asit akü denklemlerinde de görüleceği üzere, pozitif ve negatif plakalardaki reaksiyonların her ikisinin de deşarj sırasında $\mathrm{PbSO}_{4}$ oluşumu vardır. Bu durum hem negatif hem pozitif plakada gerilim değişimine neden olur. Elektrotlara sülfat iyonlarının çökelmesi nedeniyle, sülfürik asit çözeltisinin yoğunluğu azaltılacaktır. Elektrolit sülfür konsantrasyonunun Nernst elektrot potansiyellerine etkisi ve açık devre hücre gerilimi (veya elektromotor kuvveti) şu şekilde ifade edilebilir [1,2]:

$$
\begin{aligned}
& E_{P b / P b S O_{4}}=E_{P b / P b S O_{4}}^{0}+\frac{R T}{2 F} \ln \left(\frac{a_{P b S O_{4}} a_{H^{+}}^{2}}{a_{P b} a_{H_{2} S_{4}}}\right) \\
& E_{\mathrm{PbO}_{2} / \mathrm{PbSO}_{4}}=E_{\mathrm{PbO}_{2} / \mathrm{PbSO}_{4}}^{0}+\frac{R T}{2 \mathrm{~F}} \ln \left(\frac{a_{\mathrm{PbO}_{2}} a_{\mathrm{H}^{+}}^{2} a_{\mathrm{H}_{2} \mathrm{SO}_{4}}}{a_{\mathrm{PbSO}_{4}} a_{\mathrm{H}_{2} \mathrm{O}}^{2}}\right)
\end{aligned}
$$

Burada $\mathrm{E}_{\mathrm{Pb} / \mathrm{PbSO}_{4}}$ ve $\mathrm{E}_{\mathrm{PbO}_{2} / \mathrm{PbSO}_{4}}$ negatif ve pozitif Nernst elektrot potansiyelleri olup, N.Ş.A da $\mathrm{E}_{\mathrm{Pb} / \mathrm{PbSO}_{4}}^{0}-0.356$ Volt, $\mathrm{E}_{\mathrm{PbO}_{2} / \mathrm{PbSO}_{4}}^{0}+1.685$ Volt değerindedir. $\mathrm{a}_{\mathrm{PbSO}_{4}}, \mathrm{a}_{\mathrm{H}^{+}}, \mathrm{a}_{\mathrm{Pb}}, \mathrm{a}_{\mathrm{H}_{2} \mathrm{SO}_{4}}, \mathrm{a}_{\mathrm{PbO}_{2}}$ ve $\mathrm{a}_{\mathrm{H}_{2} \mathrm{O}}$ sirasıyla $\mathrm{PbSO}_{4}, \mathrm{H}^{+}, \mathrm{Pb}, \mathrm{H}_{2} \mathrm{SO}_{4}, \mathrm{PbO}_{4}$ ve $\mathrm{H}_{2} \mathrm{O}$ ya ait aktivite değerleridir. $\mathrm{R}, \mathrm{T}$ ve $\mathrm{F}$ sirasiyla gaz sabiti, sicaklık ve Faraday sabitidir [2,3].

Hücre gerilimi ( $\left.V_{\text {hücre}}\right)(4)$ denklemi kullanılarak aşağıdaki formül ile hesaplanır.

$$
V_{\text {hücre }}=E_{\mathrm{PbO}_{2} / \mathrm{PbSO}_{4}}-E_{\mathrm{Pb} / \mathrm{PbSO}_{4}}
$$




$$
=E_{P_{2 b} / \mathrm{PbSO}_{4}}^{0}-E_{\mathrm{Pbo}_{2} / \mathrm{PbSO}_{4}}^{0}+\frac{R T}{2 \mathrm{~F}} \ln \left(\frac{a_{P b} a_{\mathrm{Pbo}_{2}} a_{\mathrm{H}_{2} \mathrm{SO}_{4}}^{2}}{a_{\mathrm{PbSO}_{4}}^{2} a_{\mathrm{H}_{2} \mathrm{O}}^{2}}\right)
$$

$a_{\mathrm{PbSO}_{4}}, a_{\mathrm{Pb}}, a_{\mathrm{PbO}_{2}}$ ve $a_{\mathrm{H}_{2} \mathrm{O}}$ 1'e eşit olduğu için (5) nolu denklem şu şekilde ifade edilir.

$$
V_{\text {hücre }}=E_{P_{2 b O} / \mathrm{PbSO}_{4}}^{0}-E_{\mathrm{PbO}_{2} / \mathrm{PbSO}_{4}}^{\mathrm{O}}+\frac{R T}{\mathrm{~F}} \ln \left(\mathrm{a}_{\mathrm{H}_{2} \mathrm{SO}_{4}}\right)
$$

(6) nolu denklemden de görüleceği üzere sülfürik asit kurşun-asit akünün hücre gerilimi üzerinde güçlü bir etkiye sahiptir. Bu durum Tablo 1'de de ayrıca konsantrasyon yüzdesi ve gerilim karş1lığ ile gösterilmiştir.

Tablo 112 V Akü Asidik Konsantrasyon ve Gerilim Tablosu

\begin{tabular}{|c|c|c|}
\hline \multicolumn{2}{|c|}{ Sülfürik Asit Konsantrasyonu } & Elektromotor Kuvvet \\
\hline Molalite(mol/kg) & Konsantrasyon Yüzdesi (\%) & Gerilim (V) \\
\hline 0.05 & 0.488 & 1.762 \\
\hline 0.10 & 0.970 & 1.796 \\
\hline 0.20 & 1.925 & 1.831 \\
\hline 0.50 & 4.675 & 1.881 \\
\hline 1.00 & 8.933 & 1.919 \\
\hline 2.00 & 16.400 & 1.974 \\
\hline 3.00 & 22.737 & 2.014 \\
\hline 4.00 & 28.179 & 2.053 \\
\hline 5.00 & 32.901 & 2.090 \\
\hline 6.00 & 37.047 & 2.124 \\
\hline 7.00 & 40.707 & 2.155 \\
\hline
\end{tabular}

Pozitif $E_{\mathrm{PbO}_{2} / \mathrm{PbSO}_{4}}$ plaka $E_{\mathrm{Pb} / \mathrm{PbSO}_{4}}$ plakaya göre sülfürik asit yoğunluğuna daha fazla bağlıdır. Hücre gerilimi sıcaklığa bağlı olarak değişmekte olup bu değişim aşağıdaki denklem ile ifade edilmiştir.

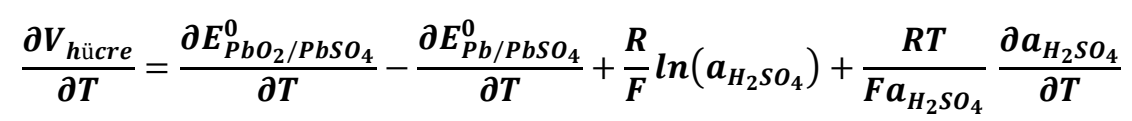

Elektrolit sıvısı içinde bulunan sülfürik asit yoğunluğunun kurşun-asit reaksiyonu üzerinde önemli etkileri vardır. Sülfürik asit yoğunluk değeri hem şarj hem deşarj reaksiyonu sırasında değişim göstermektedir. Yüksek asit yoğunluğunun kurşun-asidin ömrü üzerindeki zararlı etkisi de ayrıca bulunmaktadır $[4,5,6]$. Düşük asit yoğunluk değerlerinde indirgenemeyen kurşun sülfat kristalleri oluşumuna neden olmaktadır. Buna ilave olarak değişik sülfürik asit yoğunlukları için aküye doğrusal adım gerilimi uygulaması durumu için sülfatlaşma azalmasının asit yoğunluğundan bağımsız olarak değiştiği görülmüsstür $[7,8]$. Buradan kurşunun yüksek asit yoğunluğunun asit ömrünün lineer olarak azalmasına neden olmayacağı literatürde vurgulanmıştır [9-12].

Akünün kapasitesi içerisinde bulunan aktif malzemenin miktarına bağlıdır. Kapasite ile aktif malzeme miktarı arasında ilişkinin kurulması akünün en uygun şarj türünü ve ömür tayinini etmede oldukça önemlidir. (3) nolu kimyasal reaksiyonunda 1A-Saat kapasite eldesi için $\mathrm{PbO}_{2}, \mathrm{~Pb}$ ve $\mathrm{H}_{2} \mathrm{SO}_{4}$ aktif maddeler için miktarlar sırasıyla 4.469, 3.860 ve $3.660 \mathrm{~g}$ olarak hesaplanmıştır. 1 A-Saat kapasite eldesi için toplam aktif malzeme $11.98 \mathrm{~g}$ 'dır. Kurşun-akü asitlerde 1 kilogram aktif malzeme 83.472 A-Saat kapasiteye sahiptir. Bu değere teorik kapasite oranı denilir [13]. Örneğin; \%55 oranlı pozitif malzeme, $\% 60$ oranlı negatif malzeme kullanılan kurşun-asit bir aküde gerçek pozitif malzeme değeri $4.46 \mathrm{~g}$ $\left(\mathrm{PbO}_{2}\right) / 0.55\left(\eta^{+}\right)=8.1 \times 10^{-3} \mathrm{~kg} / \mathrm{Ah}$ olup gerçek negatif malzeme değeri sırasıyla $3.86 \mathrm{~g}(\mathrm{~Pb}) / 0.60\left(\eta^{-}\right)$ $=6.4 .1 \times 10^{-3} \mathrm{~kg} / \mathrm{Ah}$ 'dir $[10,11]$.

Sülfürik asidin $\mathrm{H}$ bölgesi ve $\mathrm{N}$ bölgesi yoğunluğu kurşun-akünün performansı üzerinde önemli etkileri bulunmaktadır. Akü elektrolit sıvısının spesifik gravite katsayısı $\left(\mathrm{g} / \mathrm{cm}^{3}\right.$ veya sp.gr) akü hücresinin doğrudan bir göstergesidir. Yüksek gravite katsayısı yüksek şarj durumunu ifade eder. Sülfürik asitin reaksiyonu boyunca iki bölge durumu oluşumu söz konusudur. H Bölgesi yoğunluğun $1.27 \mathrm{~g} / \mathrm{cm}^{3}$ altında olduğu bölge, $N$ bölgesi yoğunluğun $1.27 \mathrm{~g} / \mathrm{cm}^{3}$ üzeri olduğu bölgeyi gösterir. $\mathrm{Bu}$ iki bölge için 
yoğunluk değerinin akü şarjı üzerindeki farklı etkileri bulunmaktadır. Soğuk Marş Gücü (CCA) olarak adlandırılan marş motorunu çalıştırırken ani olarak çekilen akım miktarı sülfürik asit yoğunluğu değerine bağlıdır. Marş gücü - $18{ }^{\circ} \mathrm{C}^{\prime}$ de ölçülür ve amper (A) olarak tanımlanır. Akü üzerinde bulunan etiketlerde marş gücüne ait tanımlar genelde DIN, EN, SAE, TS gibi normlarda yapılmaktadır. Şekil 1'de marş gücü kapasitesi ve sülfürik asit yoğunluğu değişimi ilişkisi gösterilmiştir $[11,13]$.

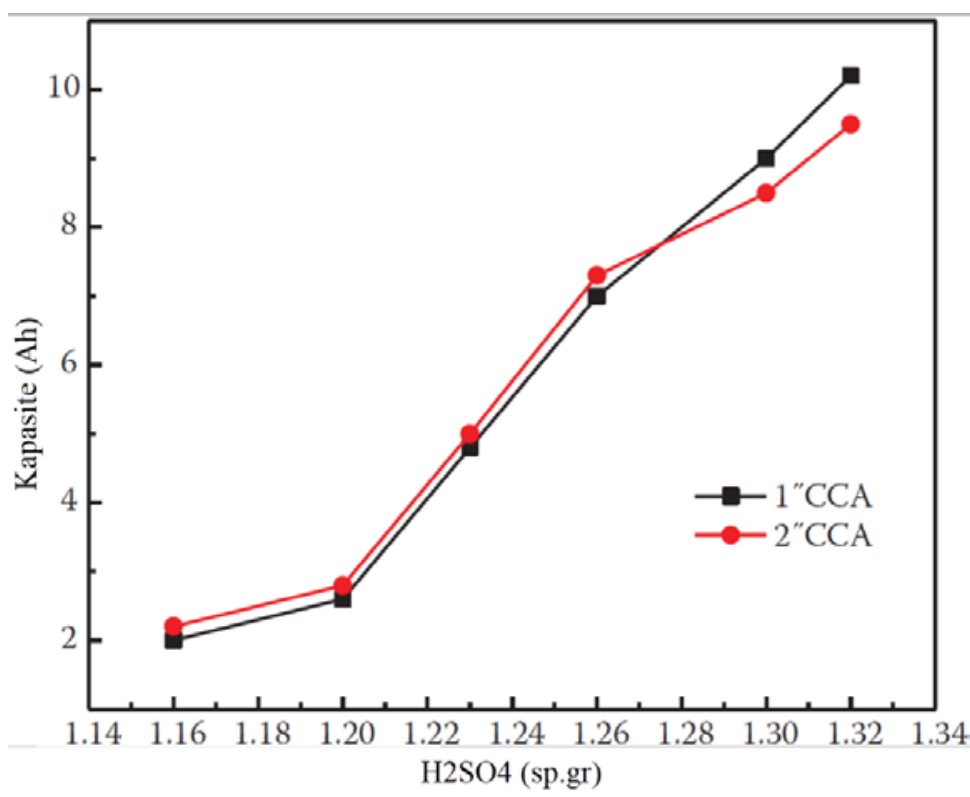

Şekil 1 Marş Gücü Kapasitesi ve Sülfürik Asit Yoğunluğu Değişimi

Literatürde şarj ve deşarj reaksiyonu süresince asit yoğunluğunun akü şarj davranışına etkisi kapsamlı olarak incelenmiştir. Sonuçlar, şarj işleminin asit yoğunluğuna ve ayrıca deşarj akımına bağlı olduğunu göstermiştir. Bu çalışmalarda, 6 hücreli bir kurşun-asit akü (2.27 V / hücre) için 13.62 V'luk kabul edilerek değerlendirmeler yapılmıştır $[12,13]$.

$$
C h_{e f f}=\frac{I_{c h} t_{e f f . c h}}{C_{n-1}}
$$

Denklem 8 de bu gerilim sınırına ulaşmak için gereken süre ( $\left.t_{\text {eff.ch }}\right)$ ve buna tekabül eden şarj kapasitesi, şarj verimliliğinin ölçüsü olarak kullanılmıştır. Şarj verimliliği $\left(\mathrm{Ch}_{\text {eff }}\right)$ yukarıdaki formül ile değiştiği tespit edilmiştir[12].

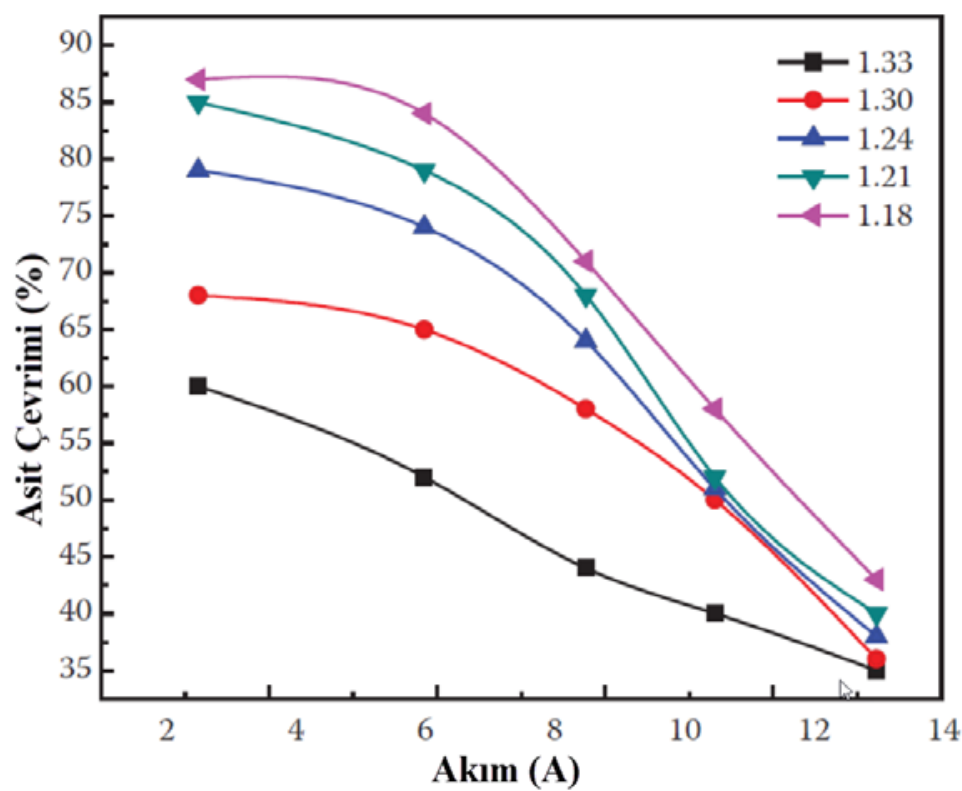

Şekil 2 Asit Yoğunluğuna Bağlı Kurşun Asit Akü Yaşam Döngüsü 
Şekil 2'de asit yoğunluğuna bağlı kurşun asit akü yaşam döngüsü grafiği verilmiştir. I deşarj akımları $\mathrm{C} / 10$ ve $\mathrm{C} / 20$ a göre alınmıştır. Burada yoğunluğu ideal akü yoğunluğuna yakın $1.30 \mathrm{~g} / \mathrm{cm}^{3}$ yoğunluğu için asit çevriminin düzenli ve dengeli olarak kurulduğu görülmektedir. Uygun asit çevrimi yapılması suretiyle akü ömrünün \% 50- \%75 arasında arttırılabileceği ortaya koyulmuştur [13,14].

Genel olarak kurşun sülfatın $\left(\mathrm{PbSO}_{4}\right)$ geri dönüşümsüz oluşumu kurşun negatif plakaların kapasite azalmasının başlıca nedenlerden biridir. Kurşun sülfatın çözünebilirliği indirgenme reaksiyonunu etkileyerek şarj işleminin negatif plaka üzerinde etkisini işlevsiz hale getirebilir. Negatif plakalarda biriken kurşunun çözülmesi için darbe frekanslı 45-70 V arası elektrik sinyalleri uygulanarak indirgenme reaksiyonunu sürekliliğini sağlayabilecek şarj işleminin negatif plaka üzerinde etkisi işlevsel hale getirebilir. Akünün şarjı tutabilmesi asit yoğunluğuna ve kristal yapısına bağlı olarak değişim gösterir [14].

\section{Kurşun Asit Aküler İçin Yenilikçi Bir Akü Koruma Cihazı Tasarımı}

Kurşun sülfat, akünün iç plakalarında oluşan ve akünün şarj kapasitesinin önemli ölçüde azalmasına neden olan bir etki olup bu etkinin elimine edilmesi kurşun sülfatın tekrar asit çözeltisine geri kazandırılması suretiyle akünün eski şarj karakteristiğine kavuşması sağlanabilir. Çalışmanın bu kısmında akülerde sülfatlaşma probleminin akü vazife görürken ve beklerken elektrokimyasal tepkime kontrolü yapılarak azaltılması veya kurşun asit akülerde kalıcı sülfatlaşmanın oluşumunun engellenmesi maksadıyla akü kutuplarından genliği ve frekansı ayarlanabilen sinyaller ile akünün uyarılarak elektrokimyasal tepkime kontrolü sağlayabilen bir akü koruma cihazına ait tasarımlar oluşturulmuştur.

\subsection{Akü Koruma Cihazı Çalışma Sistematiği}

Akü koruma cihazının kurşun sülfat kristallerini bir arada tutan kovalent bağları parçalamak için aküye genliği ve frekansı değişken darbelerin uygulanacağı bir tasarım yapılmıştır. Şekil 3'de kurşun asit akü koruma cihazına ait genel devre şeması verilmiştir.

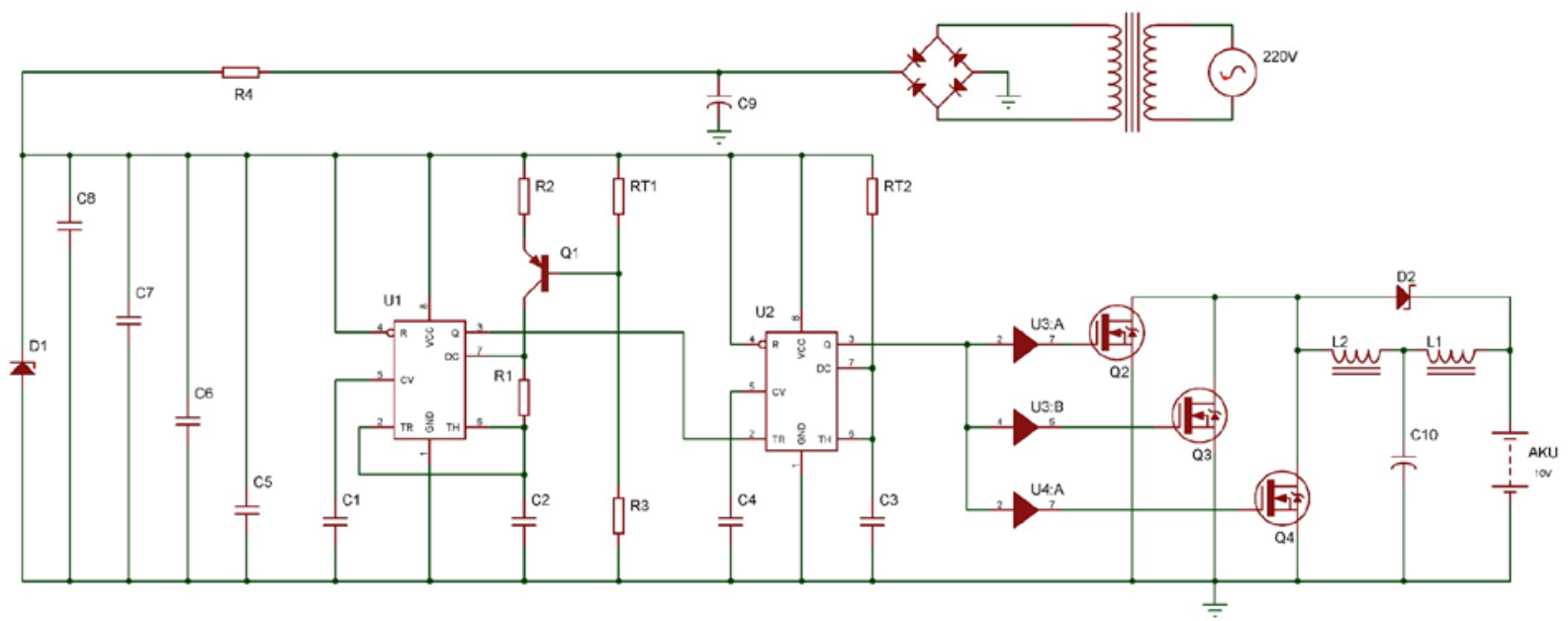

Şekil 3 Kurşun Asit Akü Koruma Cihazı Genel Devre Şeması 


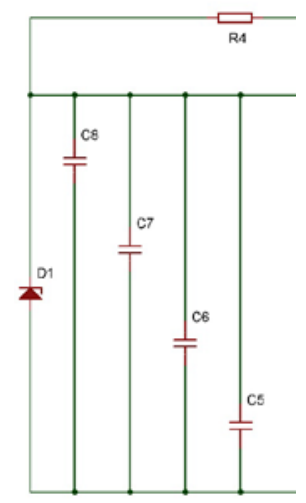

Şekil 4 Kurşun Asit Akü Koruma Cihazı İçin Koruma Direncinin Seçimi

Şekil 4'de akü koruma cihazı için koruma direncinin devre üzerinde konumlandırılması gösterilmiştir. R4 koruma direnci seçiminin doğru boyutta oluşturulması suretiyle akü koruma cihazının güvenli bir şekilde farklı çalışma gerilimlerine sahip kurşun asit akülerde kullanılması mümkün hale getirilmiştir. Tablo 2'de farklı akü gerilimleri için R4 koruma direnci boyutlandırma değerleri verilmiştir.

Tablo 2 Farklı Akü Gerilimleri İçin Koruma Direnci Boyutlandırılması

\begin{tabular}{|c|c|c|}
\hline \multicolumn{3}{|c|}{ Koruma Direncinin Özellikleri } \\
\hline $\begin{array}{c}\text { Akü } \\
\text { Gerilimi(V) }\end{array}$ & $\begin{array}{c}\text { Direnç } \\
\text { Değeri( } \boldsymbol{\Omega})\end{array}$ & $\begin{array}{c}\text { Direncin } \\
\text { Gücü(W) }\end{array}$ \\
\hline 6 & 120 & 0.5 \\
\hline 12 & 240 & 1 \\
\hline 24 & 480 & 2 \\
\hline 36 & 720 & 3 \\
\hline
\end{tabular}

Akü koruma devresinde kullanılan D1 zener diyodu akü koruma cihazının aşırı gerilimlere karşı korumasını sağlayan diğer önemli bir koruma elemanı olup, $12 \mathrm{~V}$ olarak seçilen zener diyot $12 \mathrm{~V}$ üstünde bir gerilimin ana sinyal üretici devreye ulaşmasını engelleme fonksiyonu sağlar. Ayrıca sistemi oluşabilecek parazitlerden korumak için dekuplaj(bypass) kondansatörleri kullanılmıştır. Paraziti engelleyerek stabil bir gerilim ve frekans kontrolü yapılabilmesi için dekuplaj kondansatörleri çok önemlidir. Bu nedenle devrede C5, C6, C7 ve C8 kondansatörleri 0.1uF dekuplaj kondansatörü olarak ktasarlanmıştır. Bu kondansatörler devrede kullanılan entegrelerin besleme girişlerine en yakın noktaya paralel bağlanarak devredeki gerilim üzerinde oluşan parazitliğin entegrelere etki etmesini önlemektedir. C9 kondansatörü ise devrenin ana besleme uçlarına bağlanan regüle kondansatörüdür. Şekil 5'de akü koruma cihazı için regüle koruma katmanının devre üzerinde konumlandırılması gösterilmiştir.

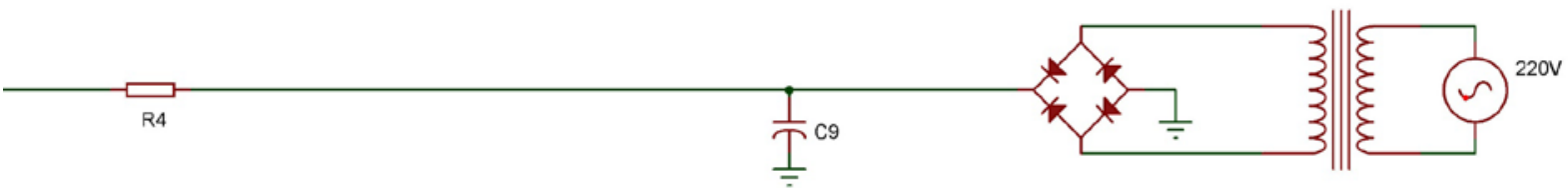

Şekil 5 Kurşun Asit Akü Koruma Cihazının Regüle Koruma Katmanı 


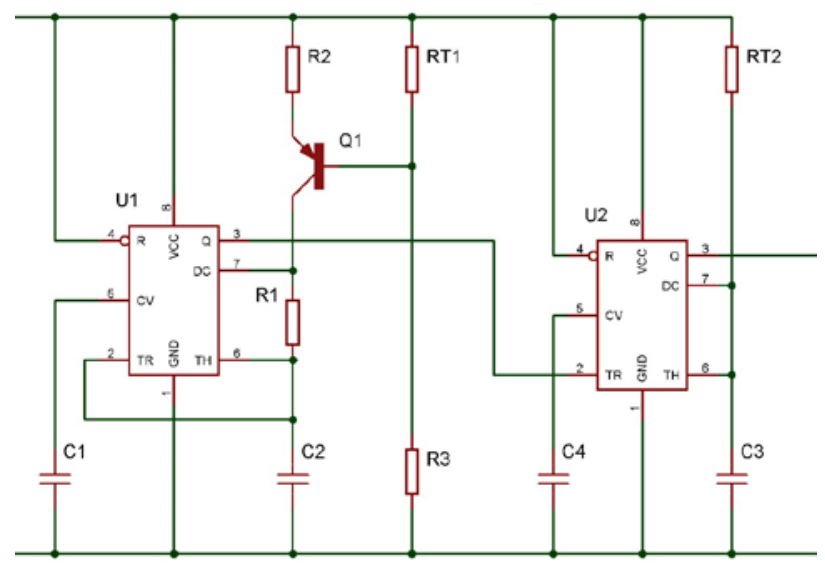

Şekil 6 Akü Koruma Cihazına Ait Sıcaklık Kontrollü Anahtarlama Elemanı Bağlantısı

Kurşun asit akülerin şarj - deşarj karakteristiğinde en önemli bir etken olan sıcaklık, koruma cihazı devresinin çalışmasında da kritik bir etkiye sahiptir. MOSFET'e uygulanan frekans büyüdükçe anahtarlamadan dolayı meydana gelen sıcaklık artışı devrenin çalışmasını dolaylı olarak da akünün zarar görmesine sebep olabilir. Anahtarlama etkisinden dolayı meydana gelen bu etkinin azaltılması için 555 entegresinin frekansının değişen sıcaklık ile ters orantılı olarak değiştirilebilmesi amacıyla RT1 ve RT2 dirençleri Termistör olarak tasarlanmıştır. Her iki anahtarlama devresinin girişine bağlanan Termistör elemanlarının bağlantısı Şekil 6'da verilmiştir. 12 V kurşun asit aküler için tasarımı yapılan koruma devresinin çalışma frekansı $30 \mathrm{kHz}$ için hesaplanmış olup darbe genişliği $33 \mu \mathrm{Sn}$ 'dir. Sıcaklık arttığında, artan sıcaklık ile ters orantılı olarak devrenin çalışma frekansı da aşağı yönlü olarak değişecektir. U1'in etrafında bulunan Q1, RT1, R2 ve R3 gibi devre elemanları, MOSFET'lerin sıcaklığını kontrol altında tutmak amacıyla bir termistör kullanmaya izin vermek için kullanılır. RT1 benzer bir dirençli NTC termistörü ile değiştirilip ve MOSFET soğutucuya termal olarak bağlanırsa, MOSFET'ler 1sınırken frekans, güç ve sıcaklık arasında bir dengeye ulaşılıncaya kadar azalır.

Koruma devresinde kullanılan ikinci 555 (U2), U1 tarafından tetiklenir. İki 555 entegresi kullanarak akünün kutuplarına uygulanan darbelerin genlik ve frekansı ayrı ayrı istenilen değerde tutulabilir. Darbe genişliği, U1'in frekansı gibi sıcaklığa bağlı olarak kontrol edilebilir. RT2 benzer değerde bir PTC termistörü ile değiştirilirse MOSFET'ler 1sınırken darbe genişliğinin azaltılması sağlanır.

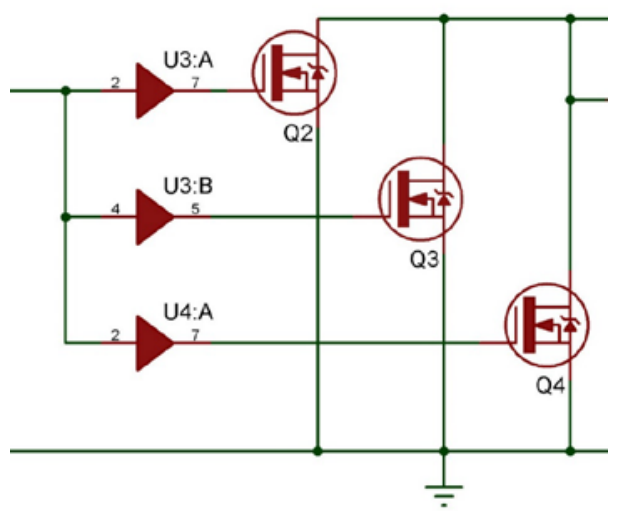

Şekil 8 Akü Koruma Cihazına Ait MOSFET ve Sürücü Bağlantısı

Koruma devresinde kullanılan U3:A, U3:B ve U4:A entegreleri TC4426 MOSFET sürücü entegrelerini göstermektedir ve MOSFET bağlantıları Şekil 8'de gösterilmiştir. Bu entegre devreler kullanılarak hem devrenin genel olarak çektiği güç aşağı çekilmiş olup hem de MOSFET daha stabil bir şekilde anahtarlanması sağlanmıştır. MOSFETler paralel bağlanarak devrenin çıkış güç katsayısı arttırılmıştır. 


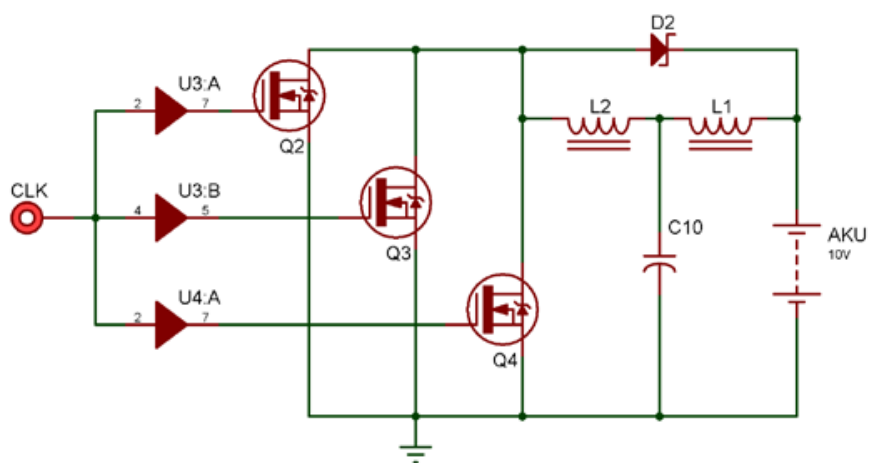

Şekil 9 Akü Koruma Cihazının Sülfatlaşmış Aküye Bağlantısı

Akü koruma cihazının genlik ve frekans kontrollü darbe çıkışının alınması maksadıyla MOSFET çıkışlarına sülfatlanmış AKÜ 'yü temsil etmek amacıyla AKU ile belirtilen $10 \mathrm{~V}$ değerinde DC bir kaynak bağlanmıştır. Sülfatlanmış akünün cihaz bağlantısı Şekil-9’da gösterilmiştir.

\subsection{Akü Koruma Cihazının Çıkış Karakteristiğinin Elde Edilmesi ve Yorumlanması}

Akü koruma cihazını $12 \mathrm{~V}$ aküye uyguladığı darbe sinyalinin gerilim ve frekans karakteristikleri elde edilmiştir. Şekil 10'da darbe sinyalinin 60.25V genlikli değeri görülmektedir. Darbe değerinden hemen sonra sinyal genliğinin "float şarj” olarak adlandırılan $13.75 \mathrm{~V}$ seviyesine geçtiği görülmektedir. $\mathrm{Bu}$ değer koruma devresinin sülfatlaşmayı ortadan kaldırmak için uyguladığı yüksek genlikli darbeden hemen sonra akünün şarj karakteristiğini bozmadan çalışma yaptığını göstermesi açısından önemlidir.

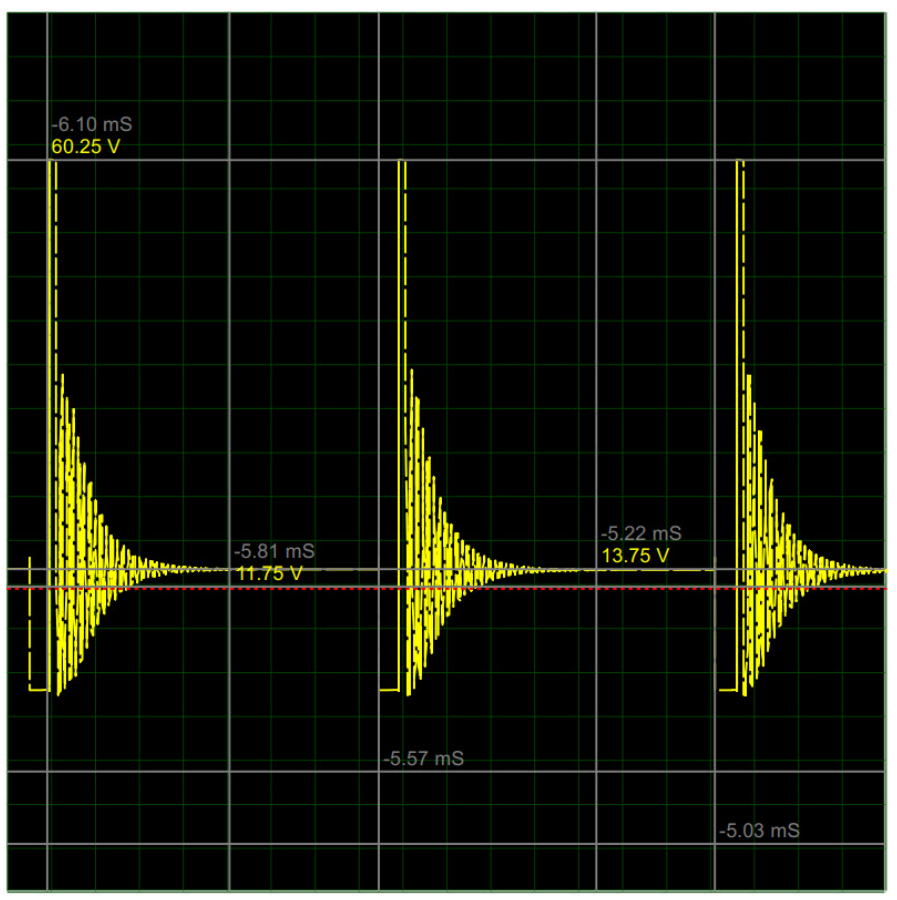

Şekil 10 Akü Koruma Cihazını 12 V Aküye Uyguladığı Darbe Sinyalinin Gerilim ve Frekans Karakteristiği-1

Uygulanan darbe sinyalinin çok kısa bir süreliğine plakaları etki altına aldığ 1 Şekil 11'de gösterilmiştir. Buna göre uygulanan sinyalin yüksek genlikli değeri sadece 10 mikrosaniye uygulanıp plakalarda ve aküye bağlı diğer elektriksel elemanlar üzerinde olası bir hasarın oluşmasının önüne geçmesi öngörülmüştür. 


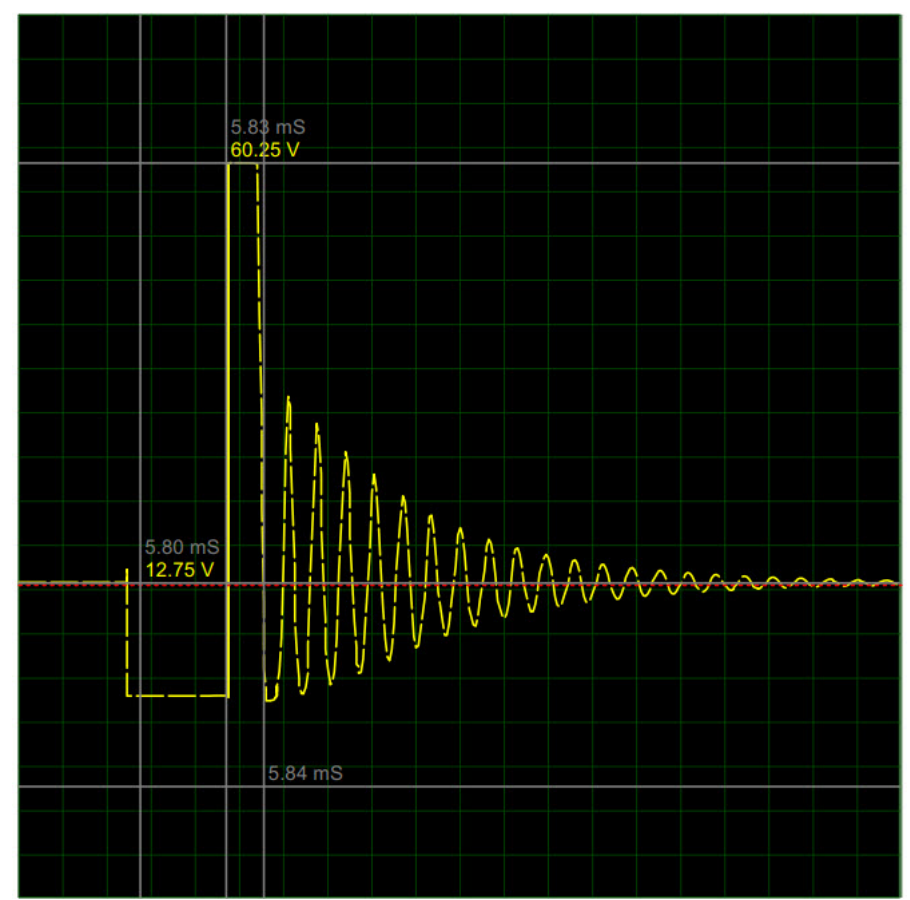

Şekil 11 Akü Koruma Cihazını 12 V Aküye Uyguladığı Darbe Sinyalinin Gerilim ve Frekans Karakteristiği-2

\section{Sonuç ve Değerlendirmeler}

$\mathrm{Bu}$ çalışmada akülerde sülfatlaşma probleminin akü vazife görürken ve beklerken elektrokimyasal tepkime kontrolü yapılarak azaltılması veya kurşun asit akülerde kalıcı sülfatlaşmanın oluşumunun engellenmesi maksadıyla akü kutuplarından genliği ve frekans1 ayarlanabilen sinyaller ile akünün uyarılarak elektrokimyasal tepkime kontrolü sağlayabilen bir akü koruma cihazına ait devre tasarımı yapılmıştır. Tasarımı yapılan bu akü koruma cihazı kullanarak, plakalarda kalıcı olarak adlandırılan sülfat çözebilir ve aktif madde geri kazanımı sağlanabilir. Tasarımı yapılan akü koruma cihazı ile plakalardan sülfat giderme işlemi adaptif sıcaklık kontrollü olarak darbe sinyalinin gerilim ve frekans ayarı ile yapılır. Aküye uygulanan bu darbe sinyali ile aküye ait elektrolit kütlesinin artması, akü iç direncin azalması ve akünün şarj-deşarj kapasitesinin artması sağlanarak

- Akünün çalışma anında şarj-deşarj uyumsuzluğuna bağlı sülfatlanmayı önlemesi

- Akü seperatörleri üzerinde bulunan kalıcı kurşun sülfat kristallerini temizlenmesi

- Akünün elektrolit kütlesinin arttırılarak çalışma performansının optimize edilmesi

- Akünün ilk kullanılmasıyla beraber kullanıldığında ömrünü iki ya da üç katına çıkarılması

- Akünün çalışma sıcaklığını sıcaklığa bağlı dirençler ile algılayarak adaptif çalışma yapması

fonksiyonlar1 yerine getirilir.

\section{Referanslar}

[1] J. Jung, L. Zhang, J. Zhang, Lead-acid Battery Technologies: Fundamentals, Materials, and Applications, CRC Press, 2015.

[2] M. Barak, Electrochemical Power Sources, Peter Peregrinus, England, 1980.

[3] Z. Zhuo et al.,"Screening and assessment of solidification/stabilization amendments suitable for soils of lead-acid battery contaminated site." Journal of Hazardous Materials, vol.288, pp. 140- 
146, 2015.

[4] Z. M. Salameh, M. A. Casacca, W. A. Lynch, "A mathematical model for lead-acid batteries,"IEEE Transactions on Energy Conversion, vol. 7(1), pp. 93-98, 1992.

[5] R. J. Brodd, K. R. Bullock, R. A. Leising, R. L. Middaugh, J. R. Miller, E. Takeuchi, "Batteries from 1977 to 2002," Journal of the Electrochemical Society, vol.151(3), 2004.

[6] C. J. Rydh, "Environmental assessment of vanadium redox and lead-acid batteries for stationary energy storage,", Journal of Power Sources, vol. 80(1), pp. 21-29, 1999.

[7] D. H. Doughty, P. C. Butler, A. A. Akhil, N. H. Clark, and J. D. Boyes, "Batteries for largescale stationary electrical energy storage," The Electrochemical Society Interface, vol. 19(3), pp. 4953, 2010.

[8] D. W. G. Lambert et al., "Advances in gelled electrolyte technology for valve- regulated leadacid batteries,” Journal of Power Sources, vol. 107, 173-179, 2002.

[9] R. C. Weast, CRC Handbook of Chemistry and Physics. CRC, Boca Raton-FL, pp. 254, 1978.

[10] K. R. Bullock, "The electromotive force of the lead acid cell and its half-cell potentials", Journal of Power Sources, vol. 35(3), pp.197-223, 1991.

[11] V. Danel, V. Plichon. "Study of Pb (II) in various H2O-H2SO4 mixtures by differential pulse polarography: solubility of lead sulphate, diffusion coefficient of $\mathrm{Pb}$ (II) and half-wave potential of $\mathrm{Pb}(\mathrm{Hg}) / \mathrm{Pb}$ (II)," Electrochimica Acta, vol. 27(6), pp. 771-774, 1982.

[12] D. N. Craig, and N. Vinal. "Solubility of lead sulfate in solutions of sulfuric acid, determined by dithizone with a photronic cell." J. Res. Natl. Bur. Stand, vol.22, pp. 55-70, 1939.

[13] D. Polov, "Lead-Acid Batteries, Technology and Operation", KLT-13, Hangzhou, China, 2000,

[14] Z. Li, Lecture Course on VRLA, China, 2003. 